\section{Microscopy of Silicified Wood}

George Mustoe, Geology Dept, Western Washington Univ. mustoeg@cc.wwu.edu

Ancient forests comprised an enormous biomass and typically flourished in lowland habitats that offered favorable conditions for fossilization, so it is not surprising that petrified wood is the most abundant terrestrial fossil. Petrifaction of wood by carbonates, sulfides, oxides, and phosphates is evidence that fossilization can occur under diverse geochemical conditions, but silicification is by far the most common process. Despite an abundance of specimens, wood petri-

ies are cited below.

Several analytical methods have been used to study petrified wood. X-ray diffraction provides a means for identifying minerals, and $\mathrm{X}$-ray fluorescence is useful for determining the elemental composition. Optical microscopy and scanning electron microscopy are useful both for analyzing mineralogical features and for observing the relict cellular anatomy. There has been a lag in the application of newer analytical methods. In particular, X-ray microanalysis is well-suited for studying the petrifaction process, but few researchers have used this method.

Silicification of wood requires an environment that inhibits $\mathrm{mi}-$
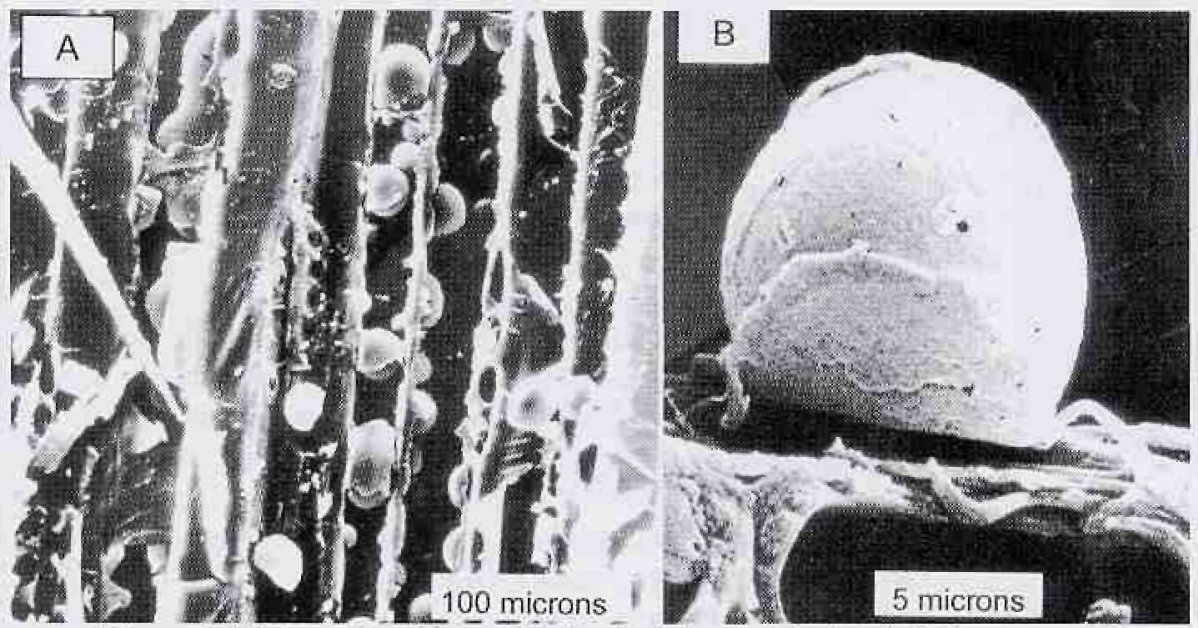
crobial decomposition, while providing favorable geochemical conditions for precipitation of silica. Protection from decomposition primarily results from burial of the wood in anaerobic sediment, because the breakdown of cellulose is caused by aerobic fungi. Silicified wood is commonly preserved in two different geologic environments: beds of volcanic ash that bury trees in upright positions, and deltas and floodplains, where tree trunks carried by rivers become buried in fine-grained fluvial sediments. Volcanic environments are particularly favorable to wood petrifaction, because volcanic glass has a relatively high solubility, providing an abundant source of dissolved silica for local groundwater.

Fossil collectors have long been aware that silicified wood from different locations may have very different physical characteristics, and specimens are commonly regarded as being either "opalized" or "agatized". Scientific research reveals that petrification is a more complicated process. Quantitative analyses show that al-

Cambridge Stereoscan SEM operated at $10 \mathrm{KV}$, secondary electron image.

faction remains an enigmatic phenomenon. Much research has been published on the taxonomy of fossil wood, and variations in growth rings have been studied during many attempts to reconstruct ancient

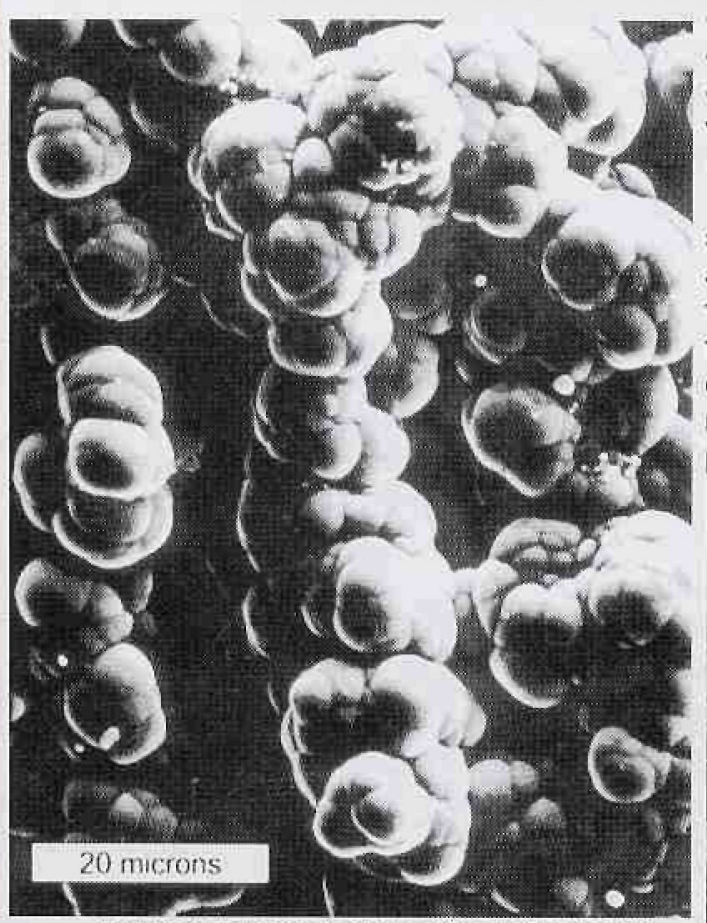

Figure 2. Longitudinal wood fibers (tracheids) in this 16-million-year-old wood from Virgin Valley. Nevada, have become encrusted in botryoidal masses of noncrystalline opal-A. Radial view, Cambridge Stereoscan SEM operated at 10 $K V$, secondary electron image.

climates. However, the process by which wood becomes mineralized

has received surprisingly little attention, particularly within the past two decades. The most important published stud-
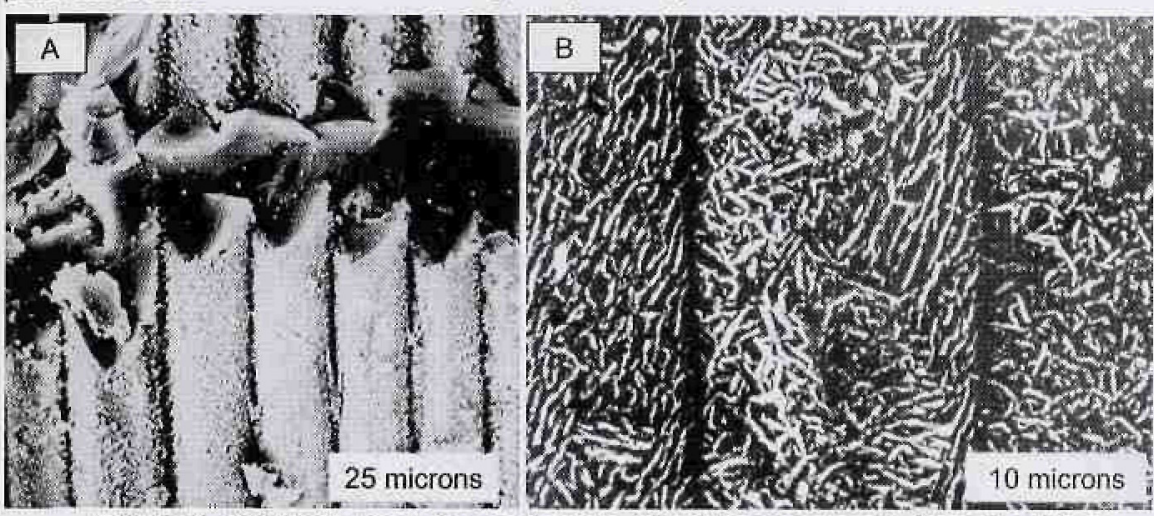

Figure 3. Silicified wood (approximately 10 million years old) from the Sierra Nevada Mountains, California, is comprised of microcrystalline cristobalite/tridymite (opal-CT). The plate-like crystals obscure cellular details. Radial view, Cambridge Stereoscan SEM operated at $10 \mathrm{KV}$, secondary electron image. 


\section{YOUR \\ SOURCE FOR \\ MICROSCOPY!}

All Nikon products include

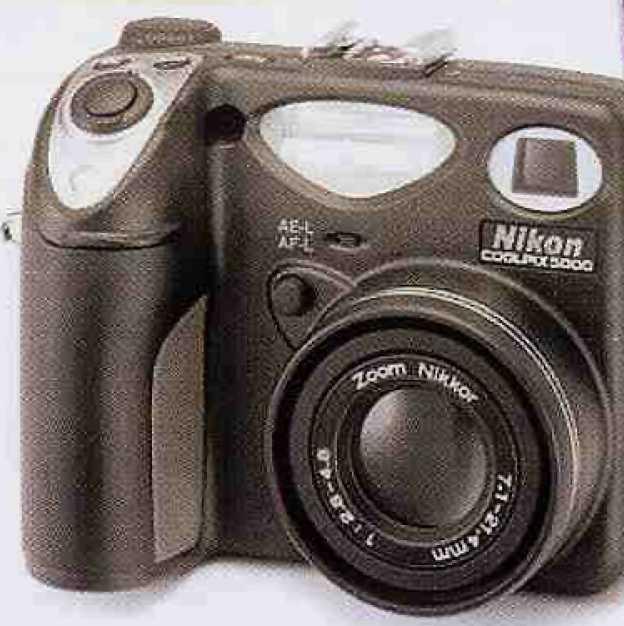

\section{MIKON COOLPIX 5000}

Incomparable image qualify with advantage photographic features!

\section{National Graphic Supply \\ Authorized Nikon Dealer \\ CALL GEORGE LAING 866.831.5118} EXT.3109

A Better Contract at a Lower Cost

- Experienced Service Engineers

- Emergency Service within 24 hours

- Regular Preventive Maintenance

- On Demand Service

Serving The Industry Since 1967
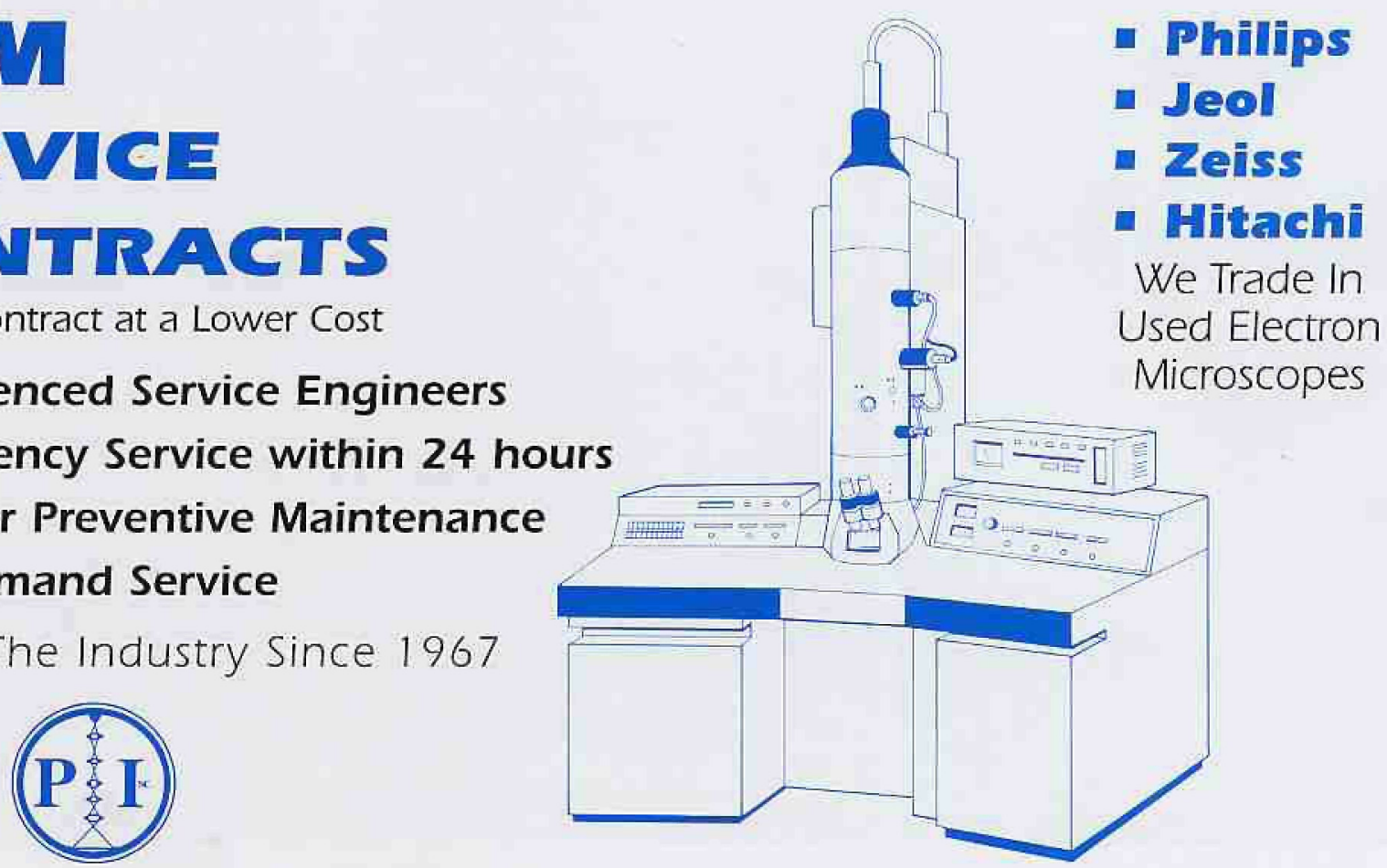

Pesto Incorporated Electron Microscope Services

808 Dekalb Pike - PO Box 648 . Gwynedd Valley, PA 19437-0648

(215) 699-6160 - FAX (215) 699-5275. pestoem@aol.com 


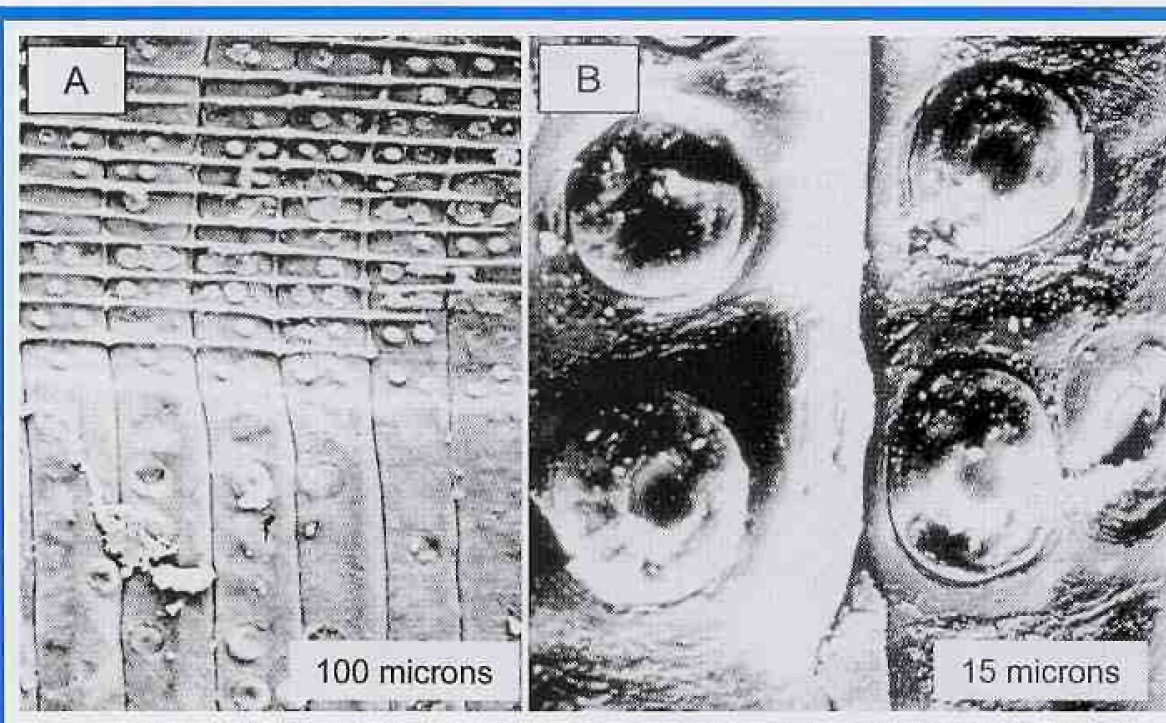

Figure 4. This 15-million-year-old specimen from central Washington is comprised of opal-CT. The very fine particle size preserves relict cellular detail in excellent detail. Radial view, Cambridge Stereoscan SEM operated at $10 \mathrm{KV}$, secondary electron image.

transformation may occur in 50,000 years or less.

The degree of preservation of cellular architecture is variable, causing some specimens of silicified wood to display spectacular anatomical details, while samples from other sites are only vaguely recognizable as fossils. The accompanying photomicrographs provide an explanation for these differences.

Loss of detail can be caused by tissue degradation prior to or during early stages of petrifaction. The fundamental process of wood decomposition is a gradual reduction in the amount of cellulose, accompanied by structural changes in the multi-layered cell walls. Decomposition begins in the central layer of the secondary cell walls, successively followed by degradation of the inner-most layer of the secondary wall, the outer-most layer of the secondary wall, and finally the deterioration of the primary wall (6). The secondary cell walls are responsible for many topographic and structural characteristics, and if these tissues are destroyed prior to silicification, the resulting fossil is relatively featureless:

Preservation of cellular detail is also related to mineralogy. The influence of particle size is illustrated in Fig. 2. This SEM photomi-
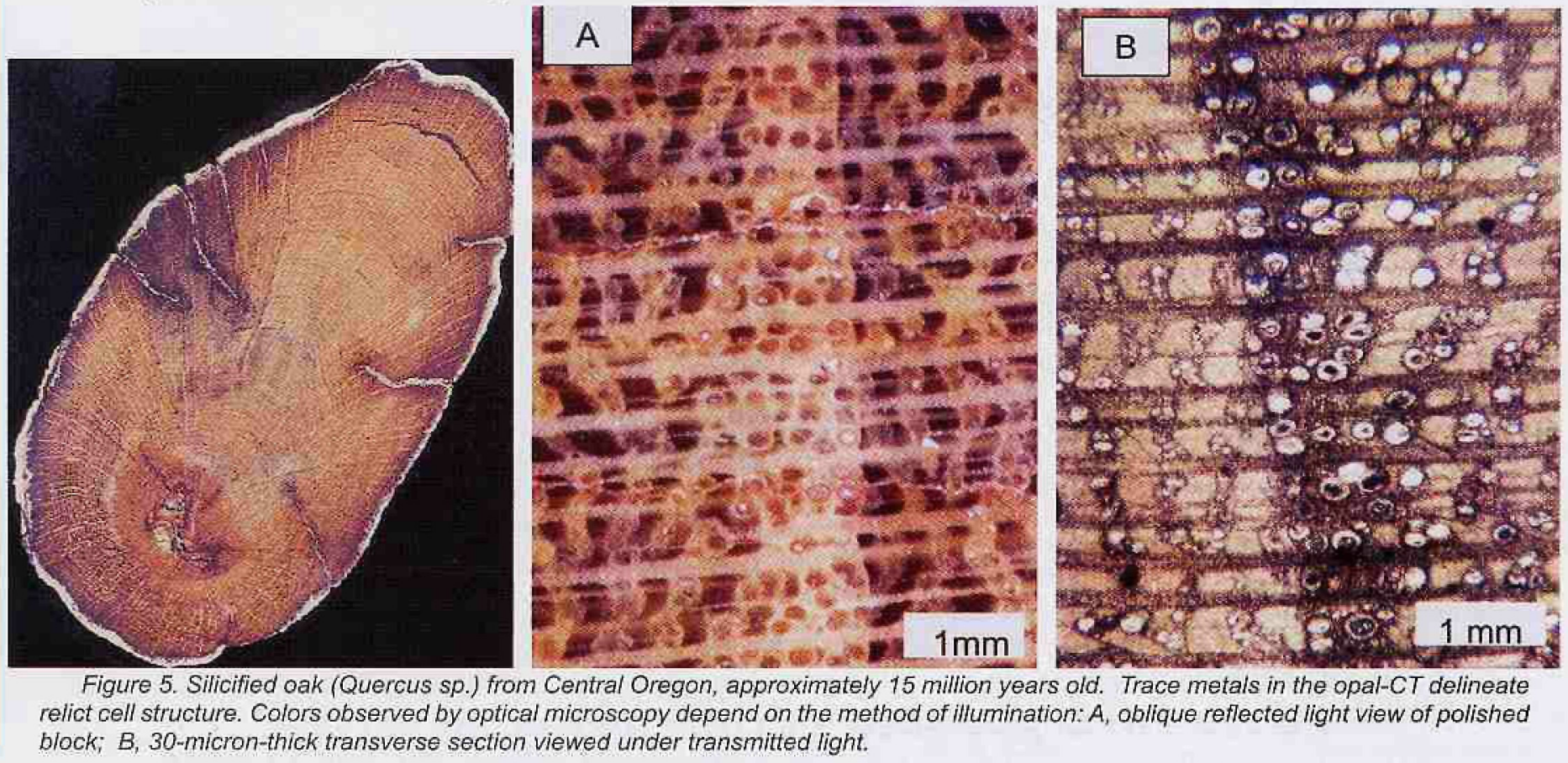

Figure 5. Silicified oak (Quercus sp.) from Central Oregon, approximately 15 million years old. Trace metals in the opal-CT delineate relict cell structure. Colors observed by optical microscopy depend on the method of illumination: $A$, oblique reflected light view of polished block; B, 30-micron-thick transverse section viewed under transmitted light. Nevada. Spherical masses of opal-A have developed as botryoidal masses aligned along wood fibers. No other cellular detail is preserved. A similar phenomenon is found in petrified wood containing opal-CT. Relatively large cristobalite crystals record poor cellular detail (Fig. 3), but if the crystal sizes are very small, opal-CT may preserve a very high degree of detail. The best preservation is commonly ound in specimens where the cell interiors (lumina) remain empty, and adjacent fibers (tracheids) remain separated by open intercellular spaces (Fig. 4).

The transition from opal to quartz may affect anatomical detail, and preservation is likely to suffer if quartz develops as relatively large crystals, particularly in those grains having distinct terminations or zonal growth patterns. In general, quality of preservation tends to decline during successive stages of silicification, because once cellular detail has been lost, it can not be regained during later episodes of mineralization. However, as crystals slowly increase in size atom-by-atom, a gentle growth process occurs that does not always destroy evidence of cell structures.

Different methods of observation may yield conflicting perceptions of the preservation of anatomical detail. Buurman (1) observed that "wood opal shows a better structural preservation than other silicifications". However, collectors of petrified wood prize the exquisite detail that is visible on polished specimens of wood that has been mineralized with cryptocrystalline quartz. These interpretations reflect the fundamental differences between images obtained from optical microscopy and the SEM. When cell lumina are filled with transparent quartz, it may be possible to examine internal pits, rays, and other anatomical details by transmitted light microscopy. Cell walls may be darkened by thin films of carbon particles or iron oxide, and these materials may remain as inclusions within the quartz to provide relict evidence of cell structure (Fig. 5). SEM views of quartz-mineralized wood specimens are typically relatively featureless because the electron emission from the sample surfaces is mostly controlled by surface topography (Fig. 6, 7). The specimen crographs show Miocene wood from Virgin Valley, orientation is also very important; SEM images generally give the 


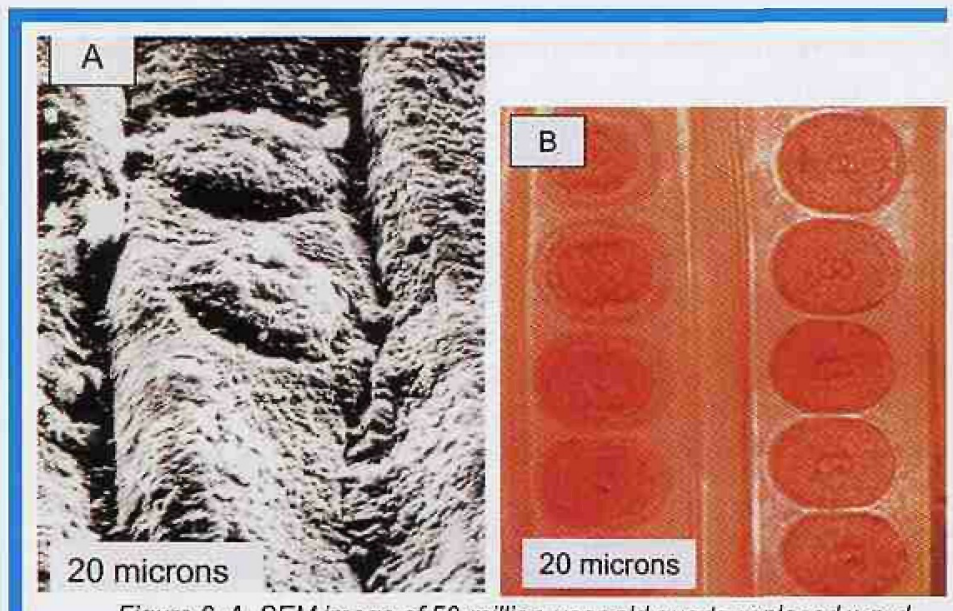

Figure 6. A, SEM image of 50-million-year-old quartz-replaced wood fibers from Oregon. The granular appearance of the mineral grains obscures three-dimensional aspects of the image. $B$. Transmitted light transverse view of 200-million-year-old fossil wood from Petrified Forest, Arizona, shows excellent relict detail, because the transparency of the quartz allows recognition of minute internal details. The red color is caused by small amounts of iron oxide. Both the Oregon and Arizona specimens break to produce conchoidal surfaces that provide no topographic expression of relict cell structure, and SEM images show little evidence of cellular preservation.
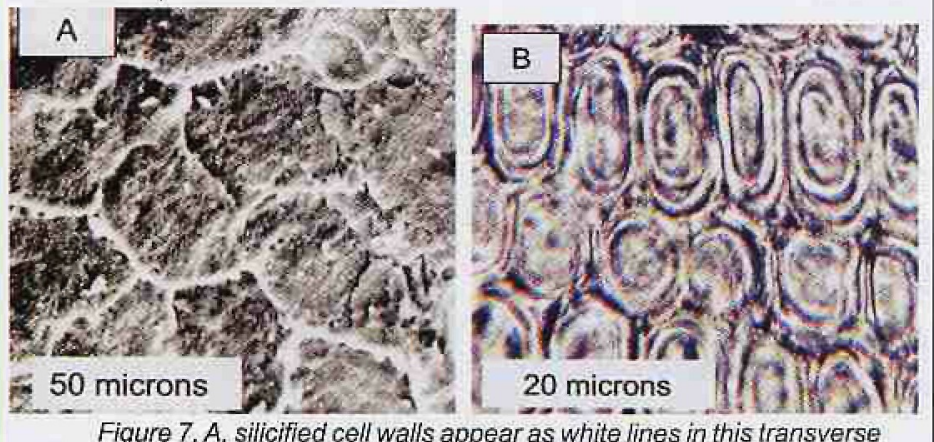

Figure 7. A, silicified cell walls appear as white lines in this transverse view of 50 -million-year-old petrified wood from central Oregon. Cambridge Stereoscan SEM operated at $10 \mathrm{KV}$, secondary electron image. B, Transmitted light image (transverse view) of 15-million-year-old petrified wood from Western Idaho reveals muiti-layered nature of cell walls. In both specimens, the cell interiors have been filled with quartz, reducing topographic contrast for SEM images. However, the mineral's high transparency is an asset for optical microscopy.

best results for radial orientations because these specimens are likely to expose cell wall outer surfaces, which are rich in anatomical detail. Optical microscopy typically shows the greatest detail with transverse sections, which have the greatest color contrast

In summary, preservation of cellular detail is partly controlled by the extent of tissue degradation prior to petrifaction, and by mineral transformations that occur during petrifaction. However, the apparent degree of preservation of anatomical details may be greatly affected by the method of observation; images obtained from a single microscopic method are seldom sufficient to accurately characterize the anatomy of ancient wood.

\section{References:}

P. Buuman, "Mineralization of fossil wood," S. Geologica 12, 1-43 (1972).

2. R.S. Mitchell and S. Tufts, "Wood opal - a tridymite-like material", American Mineralogist 58, 717-720 (1973).

3. R.F. Leo and E.S. Barghoom, "Silicification of wood", Harvard University Botanical Museum Leaflets 25 (1), 1-47, (1973).

4. C.L. Stein, "Silica recrystallization of petrified wood", Journal of Sedimentary Petrology 52, 1277-1282 (1982).

5. G. Scurfield and E.R. Segnit, "Petrifaction of wood by silica minerals", Sedimentary Geology 39, 149-167 (1984).

6. E.S. Barghoorn, Degradation of plant tissues in organic sediments, Journal of Sedimentary Petrology 22, 24-42 (1952).

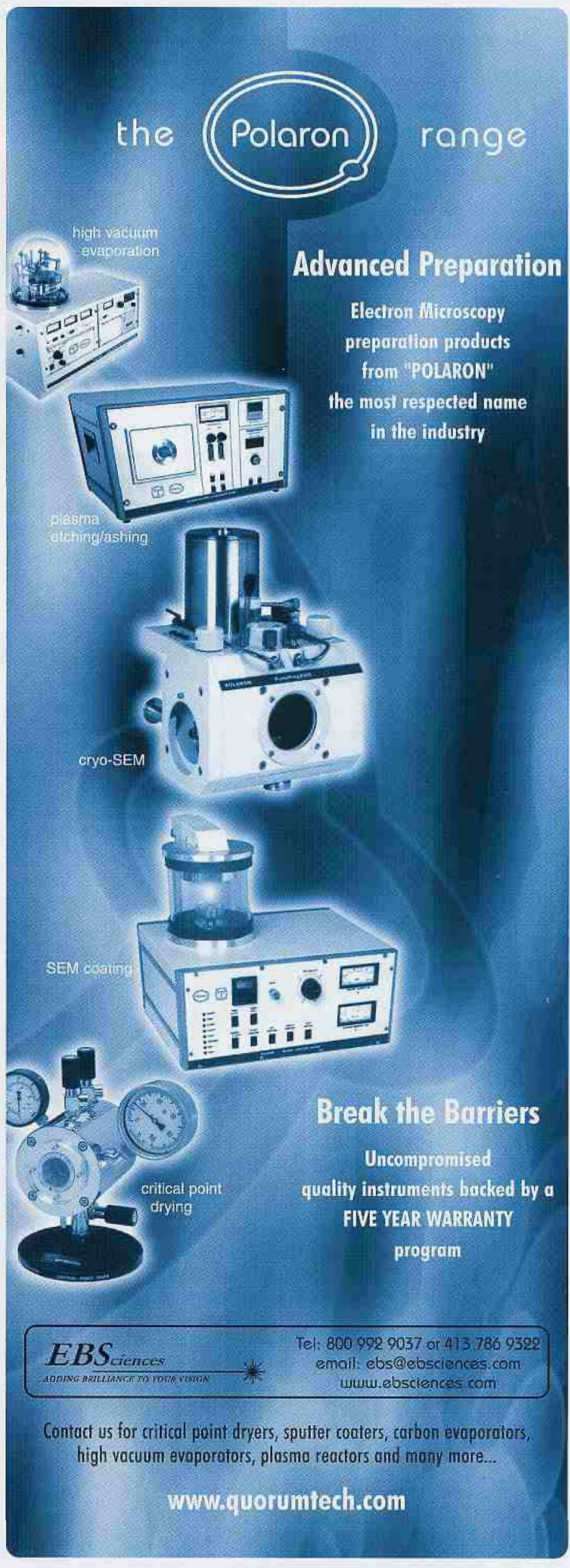

MICROSCOPY TODAY November/December 2003 